\title{
Asylum and the Museum
}

\section{Introduction}

The term asylum carries both utopian and dystopian associations. The early nineteenth-century mental asylums of the British reform movement were conceived as humane and calm retreats, yet ultimately became cruel and neglectful institutions for the supposedly incurable (Scull, 1996). Seekers of political asylum find refuge from the torture or death that threatens in their home countries but then, in the U.K. at least, they can be dogged by the media designations of "bogus" or "genuine" and detained at any stage in the process with no statutory time limit and no automatic judicial oversight (Fletcher, 2005). Asylums cast their ambiguous shadow over us all.

This essay applies the metaphor of asylum and the language of psychoanalysis toward an interpretation of the similarly ambiguous nature of museums. In his classic book Asylums, Erving Goffman defines an asylum as a closed institution that practices containment and confinement; it is "a place of residence and work where a large number of like-situated individuals, cut off from the wider society for an appreciable period of time, together lead an enclosed, formally administered round of life" (1961, p. 11). That definition can be applied usefully to an understanding of museums. Instead of human subjects, the museum houses secured inanimate objects—although, it should be kept in mind, many were once living people or animals. Its objects might receive intensive and expensive treatment to restore them to their former health or they might be sent to another museum under close surveillance. They might attract considerable moral and political interest or they might be sold or repatriated. They might be stored away with great orderliness and cleanliness or they might languish in places that are too hot, 
cold, humid, dry, or dirty. They might flourish and be admired by many people or they might become lost. As with subjects of nations, the benefits of museums are not distributed equally to their objects. Total institutions, Goffman argues, strip inmates of their former identities and give them new ones; museums give their 'inmates' not only new names and identities but also new histories, via their catalogs and classification procedures.

Psychoanalytic language can compare these functions of asylums and museums while also taking into account the moral and political considerations that the concept of asylum evokes today. Surprisingly, unlike other cultural forms, such as literature, visual art, and film, museums have escaped sustained attention from psychoanalytic perspectives. Yet, Freud himself was a collector, although interested in archaeology rather than curating (Trustram, 2011). His collection of two thousand antiquities from ancient Greece, Rome, and Egypt now lives in a museum-the house that once served as his asylum in London-and we are told that when he fled Nazi-occupied Vienna in 1938 he felt almost as anxious for the safety of his collection of artifacts as he did for the safety of his own person (Ellman, 2005, p. xi).

As this anecdote indicates, the language of object relations makes possible a conceptual comparison between the asylum and the museum and provides insight into the roles of each in our external and internal worlds. Museums and asylums share, for example, the process of differentiation and separation. That process, however, can be associated with the nature of splitting as described by Melanie Klein (Hinshelwood, 1994), with the creation of space that contains and holds as described by W.R. Bion $(1961,1962)$ and D.W. Winnicott $(1971)$, or with the provision of sanctuary and meaning as Ronald Britton (1998) described of the consulting room. This essay will argue that, by bringing to view the similar functions and processes of the asylum and the museum, the psychoanalysis of object relations reveals the ambiguities and potentialities that attach to both. 


\section{The Museum in the Mind}

The public museum saw its beginnings in Europe in the eighteenth-century Enlightenment's "dread of unreason" (Barham, 2007, p. 34). In recent decades, new practices, or the adaptation of old ones, have been grafted onto this revered institution. The modern museum is still a place for knowledge, representation, and preservation (Jordanova, 1989), but it also attempts to be a place for educational and economic regeneration (Travers, 2006). While painstakingly conserving a master painting, the museum also provides teaching in literacy and numeracy or each morning opens a shop and a café. It houses millions of objects and runs projects for the homeless. It attempts to dispose of some of its many unused objects (NMDC, 2003) through "rationalization" programs (Wilkinson, 2005) or to increase its number of visitors through audience development programs (Hooper-Greenhill, 1994). Yet, the "museum in the mind"- the conscious and unconscious mental construct that a person holds about a museum-has survived such changes because the function of the museum as a place of preservation and permanence has not been significantly affected by them. This museum in the mind - a phrase I have adapted from David Armstrong's book Organisation in the Mind (2005)—emphasizes that museums, whatever their external changes, continue to hold a consistent meaning for our inner lives.

The museum is rooted both in the Age of Reason and in our fears of the unknown. In fact, the persistence of the Enlightenment ideal of the museum as a source of rationality (Abt, 2006; O'Neill, 2006) speaks to the museum's fundamental work as a defense against our anxieties about mortality. In the museum one can observe society's disavowal of death: this place will never die, the objects will last in perpetuity. At the same time, one sees actual death in the human and animal remains that a museum preserves and displays. Death stalks us all and we can meet it in the museum. Like churches, museums both deny and bear testimony to it. To call something a "museum piece" ascribes to it a kind of death, yet the museum in the mind affirms that, despite death, life will continue. 
Christopher Bollas writes that when he visits the National Portrait Gallery he engages with a set of "notions, feelings, internal relations, and use-potentials evoked by the concept "museum"' (1992, p. 34). Such evocations derive both from our lived experience of visiting museums and from the concept as it rests in our minds. The former is examined within museology, material culture studies and museum policy reports. The latter deserves further exploration and underlies the approach taken here. As will be seen, although the museum's commitment to the sanctity of the real can impede imaginative use of museum objects, those objects need not be regarded in a solely restrictive or defensive manner; they can also be treated with freedom in a generative way.

\section{Objects in Museums}

Museums promote themselves as places of knowledge derived from concrete objects but the encounter with such objects generates complex affective and aesthetic phenomena that go far beyond the accumulation of facts. The concept of asylum - with its connotations of loss, displacement, confinement, hospitality, exclusion, privilege, and destruction-leads us to acknowledge the links that exist between inner and external objects and to recognize the profound Winnicottian way in which museums help to make life worth living.

In his book The Evocative Object World, Bollas writes: "Each person needs to feed on evocative objects, so-called 'food for thought', which stimulate the self's psychic interests and elaborate the self's desire through engagement with the world of objects" (2009, pp. 39-40). He continues:

All the time, as we amble about in our worlds, we come across objects, whether natural or man-made, material or mental. For the unconscious there is no difference between a material and a non-material evocative object; both are equally capable of putting the self through a complex inner experience. (p. 50) 
If, however, we wish to avoid thinking in dualities of objectsubject and psychic object-external object, and if inner and external objects both "elaborate the self's desire," what are we to make of institutions that exist primarily to sequester selected objects away from their subjects, to pluck objects from their original settings, and to identify them, pull them together into family groups, and put them into boxes? In answer, we can perhaps point out that the breaking up of objects in order to expose fragments of meaning lies at the heart of psychoanalysis. As Bollas explains, "Freud breaks up the figures of the dream and Winnicott breaks up the mother, and from each emerges a dynamically fragmented universe of potential meanings" (Bollas, 1999, p. 179).

\section{Seeking Refuge in Museums}

Museums today endeavor to throw off their burden as bastions of knowledge born of imperial exploitation and elite connoisseurship. In recent decades, many museums have opened their doors to community groups so as to widen their audiences, contribute to inclusive social and political goals, and justify public spending on their activities (Sandell, 2002). Some of those community groups are made up of refugees and asylum seekers. Project organizers say that they hope to make the museum relevant to them, to be able to record their heritage or give them skills to enter the labor market (Renaissance London, 2007; Goodnow, 2008). Such work takes place within the policy framework of social inclusion and community development.

A project at the Manchester Museum adopted a slightly different focus. A group of Somalian women refugees came weekly to the museum to undertake storytelling, object handling, work with textile arts, and learning English. It was thought that the lack of opportunity to talk about their cultural identity contributed significantly to the depression that some of them experienced. As refugees they had little sense of self and felt left behind by their children's greater ease at speaking English and at finding a place within their new residence in Manchester (Lynch, 2004, p. 158; 2001, p. 3). One of the women, Khadra, 
said it had taken her eight years to feel a sense of security in the U.K.:

Ask Khadra where home is, and she will say "Somalia". Ask her to explain this home to you and she will bring you an object, something she carried with her on that arduous journey [to the UK], like a talisman. Her object she says, tells others, "This is me." (Lynch, 2004, p. 158)

The irony of the women seeking refuge or asylum in the museum's ethnography collection-itself a product of colonial relationships-was not lost on the staff of the museum (Lynch, 2004; Dibley, 2005). Their visits reflected the complexity of the postcolonial relationship between the women and the museum. When they first arrived, they were intimidated and fearful, having never entered a museum, or any building, that represented colonial cultural power (Lynch, 2004, p. 162). The women viewed and handled Somali objects from the collection, including Second World War photographs from Italian Somaliland that they explained (in museum terms, interpreted) from their perspective. They were nostalgic for Somalia and proud that they could tell the museum staff about the photographs (Lynch, 2001, p. 5). They evoked memories of loss.

One might imagine that the museum provided the women with temporary asylum from their difficult lives in Manchester. They were listened to and given privileged access to special objects. They shared experiences and feelings with each other in a group that enabled them to engage in "working through" (Gould, 2011). The project can perhaps be imagined as the museum's act of reparation. Encouraging the women to offer their own meanings for the objects, rather than privileging those of the curators, appeared to democratize the museum. The museum's role, however, is complex. It has an interest in capturing their stories in order to augment the documentation of its collections; it also has a humanitarian desire to help the women, to listen to their stories.

Bernadette Lynch, one of the organizers of the project, stresses the value of the women touching the objects and, following Winnicott, the value of doing things or playing in the museum as opposed to relying only on the visual (Lynch, 2008, 
p. 268). Organizers of such programs normally discuss similar museum education and outreach programs in light of their contributions to learning and the creation of identity (Newman \& McLean, 2004; Crooke, 2006). The programs stress activity: creating, talking, moving around. Thus, visitors are offered stools to carry with them, instead of fixed seats, as an effort to leave behind the aura of museums as hallowed, quiet places intended only for an elite who know how to admire objects properly and how to behave appropriately. Now the requirement is to make, to interact, to touch.

Thinking about the museum as an asylum, however, brings attention to the fact that such work also entails a slowing down, a taking stock. The "dynamic administration" of the projects involved the creation of a bounded physical and emotional space (Barnes, Ernst, \& Hyde, 1999, p. 30). The museum is out of kilter with modernity's love of speed. It acts for the future, for an unknown posterity; it slows things down and prolongs life.

\section{Seeking Mental Health in Museums}

In more recent years some museums have turned to providing help for those with mental health difficulties. The aim is still one of providing asylum but the demons here are less overtly political, more psychological. Who Cares? Museums, Health and Wellbeing (Renaissance North West, 2011) — a series of projects that took place in six museums in the northwest of England from 2009-2011-experimented with using the museums' collections and spaces to enhance the health and wellbeing of participants. They worked with community-based organizations and professional health partners; they included a group for the homeless, a young people's psychiatric unit in a hospital, and residential and daycare centers for the elderly. The practitioners with whom they collaborated were psychiatrists, nurses, caregivers, artists, and community workers. Whereas some projects sought to enrich lives through the handling of objects, looking at art, and producing art, other projects-in which close partnerships were formed with clinicians-directly addressed the participants' mental states. 
For many decades now there has been an "arts and health" movement that for the most part uses practical creative activities (making, writing, playing music, and performing) to enhance people's health (Clift et al., 2009). For example, within the Who Cares? program one group of formerly homeless people used an exhibition at the Harris Museum and Art Gallery in Preston to write a poem that symbolically linked elements in the exhibition to their lived and felt experiences of homelessness (Froggett, Farrier, \& Poursanidou, 2011, p. 66). For a museum - the heartland of reason-to engage with madness or with wandering and stateless persons required imagination and risk-taking. Museums' apparent orderliness, their classical solidity, and housed objects represent a stark contrast to the un-housed existence of, for example, the homeless.

The Who Cares? project set out to identify the particular health benefits that derived from involvement with museums. The public nature of the museum and its objects and the potential of such public collections to meet the needs of public health emerged as especially significant and unique: participants had the use of publicly owned objects to create distinctive personal meanings. Thus, a group of young people suffering from mental health difficulties viewed the paintings in a gallery of Pre-Raphaelite art at Manchester Art Gallery. Asked to choose collectively an image that resonated with them, they selected a painting of Ophelia by Arthur Hughes (1852). Clearly, they identified with the young Ophelia, a "forsaken object" (Freud, 1917 [1915], p. 249), tormented by love and mental distress, and found in her external representation of their selves. One might say that the museum contained both the madness of Ophelia and that of the young people.

In this way, the participants in the project formed symbolic relationships with museum objects. Lynn Froggett explains the inner process: the object acts as a "symbolic third." Persons endow museum objects with a part of themselves, and simultaneously, because museum objects are highly desirable and evocative, they become joined with a particularly special part of the wider world (Froggett et al., 2011, p. 68). The power of those symbolic relationships, however, stems also from the objects being publicly owned and existing in the public domain. If an attachment can be made to an object in the public 
domain then a symbolic link can foster a sense of inclusion in the wider society:

By making a personally distinctive use of an object, I retain my uniqueness and individuality ... but I bring that individuality into relation with what the object stands for in the wider cultural field. I therefore begin to dissolve the separation I may feel from the cultural field of which others appear to be a part. (Froggett et al., 2011, p. 66)

Still, both the museum and the asylum have an ambiguous stance within the public domain. They are public but not available to all: not everyone can amble into the museum as into a public park or along the pavement. Museums are within the public domain but not an everyday part of it. Given special access, however, young people via the project found asylum or refuge for their troubled minds. The museum provided the seclusion and the space for contemplation, for free association. As such, like the consulting room, it must remain separate from the normal frame of reference. In a place that is set apart, that creates a new set of references for objects, young people can associate themselves with the suffering of others and so perhaps feel less isolated in their own sufferings. Paradoxically, while museums stand aloof from the outside community, they serve to integrate people into the wider society.

In another project, mothers came to Manchester Art Gallery from a Children's Centre in a disadvantaged area of the city. The broad aim of the project was to encourage more women to breastfeed; the particular goal of the gallery was to enable women to speak about their lives as, by and large, young women struggling with motherhood and living in an area of economic and social deprivation. They spent some time in a gallery of decorative arts and crafts and were asked to identify objects to which they felt particularly drawn. While some women chose sumptuously beautiful objects, others chose more domestic items. The latter objects worked as metaphors for how the women at times felt about themselves: as tools to be picked up and put down at will. The objects thus enabled reflection and an articulation of a sense of themselves of which they were perhaps not previously aware. 
Museums, of course, regularly provide objects for educational use. In the projects I have described, however, objects were made available for their psychological application-as objects that derived meaning from and for individuals' lives rather than from catalogs and captions. Critically, this process took place within an ethos of multiple and mutual care (Froggett et al., 2011, p. 67). "Curator" comes from the Latin curare. The museum extended its commitment to curating-caring-beyond the objects in its possession to people within the community. Far from being the judgmental and pious phrase that some took it to be, the project's title-Who Cares?-drew attention to new sources and conceptions of curating and caring. It is worth noting that the quality of care afforded to some objects in a museum is far above that which many humans receive in society.

\section{Collecting Loss}

Museum collecting and curatorial practice reflect a presumption against loss, a determination to keep and amass objects in their solid form. Some museums house many millions of objects. The riches and excesses of those museums and the lengths to which they go to preserve objects stand in sharp contrast to our everyday experience of loss. Rudi ColloredoMansfeld, an anthropologist, writes that everyday life "revolves around loss more often than preservation-luster fades, things fall apart, we eat soup" (2003, p. 246). We see around us decay and destruction-natural occurences of decay and deliberate human acts of destruction-yet the museum seems to deny those processes. Instead, it embodies the hope of those who seek asylum: that a place of refuge and hospitality can be found.

But loss persists and nothing and no one can omnipotently arrest it. Instead, museums promise continuity. D.W. Winnicott draws attention to our emotional investment in such continuity as a vital developmental need: "It is only on a continuity of existing that the sense of self, of feeling real, and of being, can eventually be established as a feature of the individual personality" (1986, p. 22). Some museums attempt to produce physical continuity: the Natural History Museum in London 
offers knowledge of 4.5 billion years of history through its collection of meteorites (Fleming, 2011). In contrast, the museum projects discussed above offer a sense of continuity that comes from self-knowledge. As Ronald Britton writes, "Through the symbol we renew our relationship with the lost primary object from which we seek satisfaction; we are as Wordsworth put it 'creator and receiver both'” (1999, p. 29). Certainly the participants in the above projects, who had experienced various kinds of losses, felt both creative and receptive responses to the objects.

Freud ascribes the "demand for immortality" to a human revolt against the pain of mourning when something we treasure has been lost (Freud, 1916[1915], p. 305). Correspondingly, Winnicott (1971) describes how loss can be managed through symbolic transitional objects such as the comfort blanket. In Winnicott's framework, museum objects act as transitional objects, occupying a space between material objects and inner reality. They exist somewhere between "the purity of the internal world and the sullied world of actual things" (Bollas, 2009, p. 84), just like the external objects that artists reshape to represent a form of their own psychic structures (p. 40). The Somalian women and the participants in Who Cares? 'found' their museum objects and then ascribed personal meanings to them. Having been reshaped in that way, the museum objects became transitional objects and symbolic representatives of the women's internal worlds (Trustram, 2013).

Winnicott argues that the attachments we develop to art and religion in adult life have their origins in the transitional phenomena of infancy. We indulge infants' needs to ascribe psychic meanings to external objects. Similarly, we indulge adults' "most intensely felt enthusiasms, emotional investments and attachments within the sphere of culture" (Kuhn, 2013, p. 1), what Winnicott calls the "little madnesses" that enable the movement between worlds of fact and fantasy necessary for wellbeing (1988, p. 107). The museum can provide a sanctuary for indulging and containing such "little madnesses," a hospitable refuge where the meanings of passionate attachments to objects can be worked through. Yet, museum objects can still be imagined as lost objects. In the museum, an object becomes symbolic, lost to normal uses, as though it was collected to become lost, as though one was collecting loss. 
In English there is ambiguity in the meaning of the word "lost." I might say, "I've lost my watch" and mean that I don't expect to see it again, or conversely, that I do in fact expect to find it. In her introduction to Freud's On Murder, Mourning and Melancholia, Maud Ellman states, "Art is the means by which we lose the object in order to call it back in a new form" and she continues that "in order to be lost the object must be looked for; it is the seeking that establishes its absence" (2005, p. xxii). I propose that the museum acts in a similar manner. The Somalian women have lost their country and their identity. In the museum they seek and find again something of what they have lost but in a new form. They have an opportunity to call their lost objects to mind (find them again) and hence to mourn.

The museum is perhaps particularly conducive to this process because, like the asylum, part of its work is to conceal. In fact, most of a collection is concealed in a store. When objects are put on display, the opportunity to 'find' them is reduced; thus projects that involve 'finding' objects behind the scenes of a museum - in its stores-can be particularly evocative. And hence the thrill of going behind the scenes in a museum and the fantasy of being locked in overnight. In its store a museum evokes most strongly its alliances with asylums. The objects are locked up, listed, named, and rarely seen by visitors. In this respect, a museum and its stores might work better than the commonly used iceberg as a metaphor for the unconscious. The vast bulk of a museum's collection is concealed in the hidden unconscious of the museum. The physical inadequacy of the stores or the wealth of unused objects in them is the embarrassment, perhaps shame, of some museums (NMDC, 2003). One is, however, also reminded of Freud watching his grandson play the "fort/da" game with the reel on a string, hiding it and then joyfully bringing it back (Freud, 1920, p. 15). Or perhaps of Winnicott's famous sentence: "It is a joy to be hidden but disaster not to be found" (Abram, 1996, p. 95). Museums offer the possibility of finding and playing with what has been hidden but not lost, and of preserving in that way a sense of continuity. 


\section{Melancholia}

Ranjana Khanna suggests, "Melancholia ... may be the corresponding affect of asylum" (2006, p. 484). If melancholia stems from a failure to mourn and to introject the lost object, then it is tempting to conclude that museums with all their unused and undigested objects are perpetual sites of institutional melancholia. Certainly the image of museums, at least in the past, as dusty, sad, and remote places brings melancholia to mind. Paul Gilroy understands melancholia as arising from a failure to mourn a lost national past and, quoting Alexander and Margarete Mitscherlich, he links melancholia to the "loss of a fantasy of omnipotence" (2005, p. 99). One can see the museum's store of colonial goods as similarly evoking a state of melancholia. In fact, museums hold onto an omnipotent fantasy that they will exist forever and defy destruction.

To suggest that museums are essentially melancholic places runs counter to the atmosphere of many museums today. I am referring, however, to the institution as a whole. The museum splits its objects into those that are displayed, worked through, and mourned, and those that stay in the store, the melancholic. Occasionally this split is confounded when objects in the store are 'played with' and then returned to the store. Such was the case with the Somalian objects, and it is tempting to suggest that the Somalian women, by using museum objects as symbolic thirds, shifted from melancholia to mourning.

Julia Reineman argues that photography renders objects melancholic because of their "temporal immobilisation" (2011, p. 1256). Photography freezes a moment and in so doing removes the possibility of future change. In a similar manner, museums freeze an object and render it immobile. The object is no longer used for its original purpose. In fact, it is likely that it will never be used but will sit in the store, supposedly forever. Thus, in the act of collecting and placing objects in museums, we remain loyal to our melancholic ego: we remove objects from the world and temporality and render them inactive.

Little has been written about the process of collecting from a psychoanalytic perspective. Peter Subkovski writes, "Collecting represents a specific form of object relating and 
way of handling primary loss trauma, which is different from addiction, compulsion, or perversion" (2006, p. 383). While collecting can be imagined as a symbolic process of remembering and repeating, it cannot be considered a working through: consider Freud's paper "Remembering, Repeating and Working Through" (Freud, 1914). The melancholic collector, who accumulates objects but is unable to work them through, might make them available, via a museum, for others to work through and to mourn losses. In that sense, the act of the collector too is about collecting loss.

Longing for the past and dreaming about the future are central to being human. The museum embodies this preoccupation with times past and future. Its business is to date objects and ensure that they will live on into a timeless future, forever. Siri Hustvedt suggests that for traumatized people the past is in the present: "it's possible to understand trauma as a form of speechlessness that is located in an ongoing present" (2010, p. 57). Museums similarly exist beyond speech. Like traumatic experiences, their objects have a time of origin but they continue to exist in a condition of timelessness. Museums revolve around constitutional, on-going experiences of primary loss. One is reminded of T.S. Eliot's enigmatic line from "The Waste Land": "These fragments I have shored up against my ruins" (1922/1971).

Loss brings about social and personal transformation and a train of activity in the bid to make meaning (Leader, 2008, p. 107). Museums can be imagined as society's permanent adjustment to loss; hence their apartness from society. Like religion, they address human issues of mortality that cannot be borne on a daily basis, and like churches, they occupy a transitional space between the living and the dead. The objects in stores wait to be found and used when they can be borne, when they can bear witness to loss and can symbolize it.

John Leighton, director of the National Galleries of Scotland, recently defended the expenditure of $£ 45$ million of mostly public money on the purchase of Titian's "Diana and Callisto" (1559), stating, "we invest in national collections for perpetuity ... millions of people over decades and centuries to come will have inspiration, education and enjoyment from works like this" (Leighton, 2012). In a time of austerity im- 
posed upon many of the present generation, enormous sums of money are found to invest in the wellbeing of unknown future generations. Leighton's statement brings to mind what Susan Crane (2006) describes as "the conundrum of ephemerality": museums seek to conserve objects, to keep them as they are, and yet work within changing political, economic, and scholarly contexts. I would suggest that the apparent long-sighted vision of museum directors and heritage policy makers like Leighton, unusual amongst public servants and politicians, works as a defense against paranoid and depressive anxieties. It provides reassurance about the future: all will not be lost.

\section{Conclusion: The Relational Museum}

In her examination of museum practice, Sandra Dudley advocates "a turn to the material" (2010, p. 13), that is, a renewed respect for the materiality of objects and their multisensorial dialogue with human subjects. This engagement with the materiality of objects is evident in the projects described in this essay. They also speak to a relational turn, in which the focus shifts from how best an object can yield its meaning to how best a subject can be helped to talk about himself or herself in a meaningful way. The center of concern becomes the meaning that can be produced by a dynamic interaction between subjects and objects, the meaning that covers not just the object but the subject too. In the language of psychoanalysis and psychotherapy, the inner and outer dialogues that a subject might have with a museum object have the potential to bring about transformational changes, including the "expansion of imaginative capacity, nurturing of creative illusion, reparative emotional states, multiplication of relational potentials" (Froggett et al., 2011, p. 91). Yet, relational work also runs counter to the philosophy of the museum that seeks to identify, classify, and organize, and hence bring closure to the nature of an object. Relational work tries to disrupt, "to be lost in thoughts, to be inside the complexity of subjectivity" (Bollas, 1992, p. 49). Thus, it pulls the museum away from an exclusive preoccupation with objectivity-what Bollas calls the "normotic" (1987, p. 135)—toward subjectivity. 
Bollas describes the world of a person unable to symbolize experiences as "a world of meaningless plenty" (1987, p. 137). A museum's plenty becomes meaningful when elaborated by people's subjectivity, when played with. As we have seen, that process of acquiring meaning is inherently ambiguous. Museums love the materiality of objects, the objectivity of objects, but as the projects described in this essay show, the museum also enables the expression of subjective states of mind through that materiality, which can then symbolize those inner states.

\section{References}

Abram, J. (1996). The language of Winnicott. London: Karnac.

Abt, J. (2006). The origins of the public museum. In S. Macdonald (Ed.), A companion to museum studies (pp. 115-134). Oxford: Blackwell.

Armstrong, D. (2005). Organisation in the mind: Psychoanalysis, group relations and organisational consultancy. London: Karnac.

Barham, P. (2007). Rubbing shoulders with unreason. London Review of Books, 29(5), 34-36.

Barnes, B., Ernst, S., \& Hyde, K. (1999). An introduction to groupwork: A group-analytic perspective. London: Macmillan.

Bion, W.R. (1961). Experiences in groups. London: Tavistock.

Bion, W.R. (1962). Learning from experience. London: Tavistock.

Bollas, C. (1987). The shadow of the object: Psychoanalysis of the unthought known. London: Free Association Books.

Bollas, C. (1992). Being a character: Psychoanalysis and self experience. London: Routledge.

Bollas, C. (1999). The mystery of things. London: Routledge.

Bollas, C. (2009). The evocative object world. London: Routledge.

Britton, R. (1998). Belief and imagination. London: Routledge.

Britton, R. (1999). Primal grief and 'petrified rage': An exploration of Rilke's Duino Elegies. In D. Bell (Ed.), Psychoanalysis and culture: A Kleinian perspective (pp. 27-47). London: Routledge.

Clift, S., Camic, P.M., Chapman, B., Clayton, G., Daykin, N., Eades, G., Parkinson, C., Secker, J., Stickley, T., \& White, M. (2009). The state of arts and health in England. Arts and Health, 1(1), 6-35.

Colloredo-Mansfield, R. (2003). Introduction: Matter unbound. Journal of Material Culture, 8(3), 245-254.

Crane, S. (2006). The conundrum of ephemerality: Time, memory and museums. In S. Macdonald (Ed.), A companion to museum studies (pp. 98-109). Oxford: Blackwell.

Crooke, E. (2006). Museums and community. In S. Macdonald (Ed.), A companion to museum studies (pp. 171-185). Oxford: Blackwell.

Dibley, B. (2005). The museum's redemption: Contact zones, government and the limits of reform. International Journal of Cultural Studies, 8(5), 5-27.

Dudley, S.H. (2010). Museum materialities: Objects, engagements, interpretations. Oxon: Routledge.

Eliot, T.S. (1922/1971). The waste land. V. Eliot (Ed.). London: Faber and Faber.

Ellman, M. (2005). Introduction. In S. Freud, On murder, mourning and melancholia (pp. vii-xxvii). London: Penguin Classics.

Fleming, M. (2011). Natural history, global history. Kingston Centre for the Historical Record. Retrieved from http://backdoorbroadcasting.net/2011/06/providingpublic-history-challenges-and-opportunities/

Fletcher, K. (2005). A minimum of charity. London Review of Books, 27(6), 30-34. 
Freud, S. (1914). Remembering, repeating and working through (Further recommendations on the technique of psycho-analysis II). Standard Edition (Vol. 12, pp. 145-156). London: Hogarth Press.

Freud, S. (1916[1915]). On transience. Standard Edition (Vol. 14, pp. 303-307). London: Hogarth Press.

Freud, S. (1917[1915]). Mourning and melancholia. Standard Edition (Vol. 14, pp. 237-258). London: Hogarth Press.

Freud, S. (1920). Beyond the pleasure principle. Standard Edition (Vol. 18, pp. 7-64). London: Hogarth Press.

Froggett, L., Farrier, A., \& Poursanidou, K. (2011). Who cares? Museums, health and wellbeing research project. Retrieved from http://issuu.com/renaissancenorthwest/ docs/who_cares_report_final

Gilroy, P. (2005). Postcolonial melancholia. New York: Columbia University Press.

Goffman, E. (1961). Asylums. London: Penguin.

Goodnow, K. (2008). Museums, the media and refugees: Stories of crisis, control and compassion. London: Museum of London.

Gould, L.J. (2011). Collective working through: The role and function of memorialisation. Organisational and Social Dynamics, 11(1), 79-92.

Hinshelwood, R.D. (1994). Clinical Klein. London: Free Association Books.

Hooper-Greenhill, E. (1994). The educational role of the museum. London: Routledge.

Hustvedt, S. (2010). The shaking woman. London: Hodder and Stoughton.

Jordanova, L. (1989). Objects of knowledge: A historical perspective on museums. In P. Vergo (Ed.), The new museology (pp. 22-40). London: Reaktion.

Khanna, R. (2006). Asylum. Texas International Law Journal, 41, 471-490.

Kuhn, A. (2013). Little madnesses: An introduction. In A. Kuhn (Ed.), Little madnesses: Winnicott, transitional phenomena and cultural experience (pp. 1-10). London: I.B. Tauris.

Leader, D. (2008). The new black: Mourning, melancholia and depression. London: Penguin. Leighton, J. (2012, March 1). Front Row: Titian's Diana and Callisto. BBC Radio 4.

Lynch, B. (2001). If the museum is the gateway, who is the gatekeeper? Engage Review, $11,1-12$.

Lynch, B. (2004). Access to collections and affective interpretation with objects in the museum. (Doctoral dissertation). University of Manchester.

Lynch, B. (2008). The amenable object: Working with diaspora communities through a psychoanalysis of touch. In H.J. Chatterjee (Ed.), Touch in museums: Policy and practice in object handling (pp. 261-272). Oxford: Berg.

Newman, A., \& McLean, F. (2004). Capital and the evaluation of the museum experience. International Journal of Cultural Studies, 7(4), 480-498.

National Museum Directors Conference (NMDC). (2003). Too much stuff? Disposal from museums. London: National Museum Directors Conference.

O’Neill, M. (2006). Essentialism, adaptation and justice: Towards a new epistemology of museums. Museum Management and Curatorship, 21, 95-116.

Reineman, J. (2011). Between the imaginary and the real: Photographic portraits of mourning and of melancholia in Argentina. International Journal of Psychoanalysis, 92, 1241-1261.

Renaissance London. (2007). Refugee heritage project. London: Renaissance London.

Renaissance North West. (2011). Who cares? Museums, health and wellbeing research project. Retrieved from http://issuu.com/renaissancenorthwest/docs/whocares_final_midres

Sandell, R. (Ed.). (2002). Museums, society, inequality. London: Routledge.

Scull, A. (1996). Asylums: Utopias and realities. In J. Carrier \& D. Tomlinson (Eds.), Asylum in the community (pp. 7-17). London: Routledge.

Subkovski, P. (2006). On the psychodynamics of collecting. International Journal of Psychoanalysis, 87, 383-401.

Travers, T. (2006). Museums and galleries in Britain: Economic, social and creative impacts. London: National Museum Directors Conference \& Museums, Libraries and Archives Council. 
Trustram, M. (2011). Response to 'Freud's Antiquities.' Psychodynamic Practice, 17(1), $73-80$.

Trustram, M. (2013). The little madnesses of museums. In A. Kuhn (Ed.), Little madnesses: Winnicott, transitional phenomena and cultural experiences (pp. 187-201). London: IB Tauris.

Wilkinson, H. (2005). Collections for the future. London: Museums Association.

Winnicott, D.W. (1971). Playing and reality. London: Tavistock.

Winnicott, D.W. (1986). Home is where we start from. London: Penguin.

Winnicott, D.W. (1988). Human nature. London: Free Association Books. 